\title{
Bifidobacteria and Their Molecular Communication with the Immune System
}

\author{
Lorena Ruiz, Susana Delgado, Patricia Ruas-Madiedo, Borja Sánchez* and \\ Abelardo Margolles
}

Dairy Research Institute, Spanish National Research Council (Instituto de Productos Lácteos de Asturias - CSIC), Villaviciosa, Spain

OPEN ACCESS

Edited by:

Rustam Aminov,

University of Aberdeen,

United Kingdom

Reviewed by:

Douwe Van Sinderen,

University College Cork, Ireland

Julio Villena,

Centro de Referencia para

Lactobacilos, Argentina

${ }^{*}$ Correspondence:

Borja Sánchez

borja.sanchez@csic.es

Specialty section:

This article was submitted to

Microbial Immunology,

a section of the journal

Frontiers in Microbiology

Received: 11 August 2017 Accepted: 15 November 2017 Published: 04 December 2017

Citation:

Ruiz L, Delgado S, Ruas-Madiedo P,

Sánchez B and Margolles A (2017) Bifidobacteria and Their Molecular Communication with the Immune System. Front. Microbiol. 8:2345. doi: 10.3389/fmicb.2017.02345
Bifidobacterium represents a genus within the phylum Actinobacteria which is one of the major phyla in the healthy intestinal tract of humans. Bifidobacterium is one of the most abundant genera in adults, but its predominance is even more pronounced in infants, especially during lactation, when they can constitute the majority of the total bacterial population. They are one of the pioneering colonizers of the early gut microbiota, and they are known to play important roles in the metabolism of dietary components, otherwise indigestible in the upper parts of the intestine, and in the maturation of the immune system. Bifidobacteria have been shown to interact with human immune cells and to modulate specific pathways, involving innate and adaptive immune processes. In this mini-review, we provide an overview of the current knowledge on the immunomodulatory properties of bifidobacteria and the mechanisms and molecular players underlying these processes, focusing on the corresponding implications for human health. We deal with in vitro models suitable for studying strainspecific immunomodulatory activities. These include peripheral blood mononuclear cells and T cell-mediated immune responses, both effector and regulatory cell responses, as well as the modulation of the phenotype of dendritic cells, among others. Furthermore, preclinical studies, mainly germ-free, gnotobiotic, and conventional murine models, and human clinical trials, are also discussed. Finally, we highlight evidence supporting the immunomodulatory effects of bifidobacterial molecules (proteins and peptides, exopolysaccharides, metabolites, and DNA), as well as the role of bifidobacterial metabolism in maintaining immune homeostasis through cross-feeding mechanisms.

Keywords: bifidobacteria, Bifidobacterium, microbiota, immunomodulation, T cell response, PRRs, MAMPs

\section{EARLY COLONIZATION OF BIFIDOBACTERIA AND PROPER IMMUNE DEVELOPMENT}

Microbiota establishment in newborns involves the assembly of a novel microbial community, a process that is dependent on several factors, including the mother's physiology (age, metabolic state, lifestyle, or even the potential transfer of microorganisms from mother to child before birth), mode of delivery, genetic background, environmental factors, type of feeding and early antibiotic use, among others (Hill et al., 2017). Similar results were found for preterm neonates, which are less abundantly colonized by bifidobacteria (Arboleya et al., 2012). Infant feeding is also a critical 
factor for bifidobacterial establishment in the gut, and breast-fed infants have been shown to possess higher levels of bifidobacteria than formula-fed infants (Yatsunenko et al., 2012); these high bifidobacterial levels decrease after breast milk cessation (Davis et al., 2016).

Pioneering studies revealed reduced levels of bifidobacteria in the gut microbiota composition of infants at high risk of atopic disease at 3 weeks and 3 months of age, and a higher incidence of atopic disease was found in this group of infants by the age of 1 year (Kalliomaki et al., 2001). Similarly, lower bifidobacterial levels were found in 3-month-old infants who later developed atopy at 2 years of age, or asthma at 4 years of age (Fujimura et al., 2016). All these data point to a critical role for bifidobacteria in the maturation of our immune system from gestation to childhood, suggesting that the low abundance of these early colonizers is associated with a deviated physiological state in infancy. Indeed, current evidence suggests a role of early life bifidobacteria establishment in programming future health. Therefore, it is of great importance to know the specific strains (and species) able to regulate immune responses, either directly or indirectly through the modulation of the gut microbiota, and the underlying mechanisms, in order to design dietary strategies focused on preventing immune-related disorders.

\section{STRAIN-SPECIFIC IMMUNOMODU- LATORY ACTIVITIES/IN VITRO AND IN VIVO MODELS OF STUDY}

\section{In Vitro Models}

In vitro models have important limitations but they enable the preliminary screening of the effects that bacterial cells or fractions might have on different components of the immune response (Kobayashi et al., 2017). Most in vitro models based on immune cells employ peripheral blood mononuclear cells (PBMCs). In this way, whole cells of B. longum, B. breve, B. bifidum, and $B$. animalis subsp. lactis strains demonstrated capacity to induce dendritic cell (DC) maturation, and a species/straindependent $\mathrm{T}$ cell polarization response (Medina et al., 2007; López et al., 2010; Nicola et al., 2016). These studies revealed that, while $B$. animalis and many $B$. longum strains induced the production of the modulatory cytokine IL10 to varying degrees, the greatest strain-dependent differences were displayed in $\mathrm{TNF} \alpha$ and INF $\gamma$ production (Figure 1). Stimulation of PBMCs with subcellular fractions of bifidobacteria, including cytoplasmic, surface extracts, and supernatants, has also allowed the identification of molecular determinants of the elicited effects. For instance, a trypsin-labile cytoplasmic fraction of a B. bifidum strain was identified as the effector of $\mathrm{CD}^{+}{ }^{+} \mathrm{T}$ cell activation; and supernatants of B. breve BB99 and B. longum 1941 exerted a regulatory $\mathrm{T}$ cell induction (Mouni et al., 2009). PBMC models are thus useful to identify desirable immune profiles in probiotic strain screenings (Liu et al., 2016).

Other in vitro models differentiate DCs, a specialized type of antigen presenting cells, from monocytes. DCs are regarded as the main guardians of the intestinal mucosa and are important in initiating the microbiota-immune system cross-talk. Their pattern recognition receptors (PRRs) interact with specific microbial-associated molecular patterns (MAMPs), which orchestrated molecular cascades that will determine the nature of the immune response (Hoarau et al., 2008; Wittmann et al., 2013). In vitro differentiated DCs allowed the identification of specific domains of a $B$. bifidum surface protein and the exopolysaccharide (EPS) of B. longum 35624, as the effectors of the immune responses elicited by the strains (Guglielmetti et al., 2014; Schiavi et al., 2016). DC models have also been used to predict the anti-inflammatory potential of bifidobacterial strains/molecules in specific population groups; for instance, bifidobacteria improved antigen uptake and processing by DC from Crohn's disease patients (Strisciuglio et al., 2015).

Other in vitro models using immune cells employ murine splenocytes (Tanabe et al., 2008; Srutkova et al., 2015), macrophage-like cell lines (He et al., 2002; Lee et al., 2012; Mokrozub et al., 2015), or cells isolated from the gut-associated lymphoid tissues (GALT) (Hidalgo-Cantabrana et al., 2014), although they have not been widely used to examine the immunomodulation potential of bifidobacteria and thus their utility to predict immune responses is yet to be confirmed.

The immunomodulation potential of bifidobacteria has also been studied on enterocytes including Caco-2 or HT29 cell models (Bahrami et al., 2011; Chichlowski et al., 2012; Khokhlova et al., 2012; Arboleya et al., 2015; Sánchez et al., 2015; Luongo et al., 2017). Although the immune response of epithelial cells is much more limited than the one exerted by specialized immune cells, enterocytes are more directly exposed to the intestinal milieu and are considered to play a key role in initiating the bifidobacteria-host interactions.

Beyond that, co-culture systems employing both immune and intestinal cells have also been implemented to study microbial-host interactions and promise to overcome some of the limitations of single cell type models (Duell et al., 2011). However, few studies have used them on bifidobacteria (PozoRubio et al., 2011). The application of organized multicellular systems like intestinal organoids for these kinds of studies is envisaged (Noel et al., 2017).

\section{In Vivo Models}

Germ-free (GF) and conventional in vivo models, including healthy and disease-induced models, have shed light on the immune modulation capability of bifidobacterial strains including live and heat-killed cells (Sugahara et al., 2017). Screening of a large collection of gut symbionts on GF mice identified a $B$. adolescentis strain which induces a robust Th17 response, albeit not inducing intestinal inflammation (Tan et al., 2016). However, immune responses may vary strongly depending on the health status of the host, as the human sera of Clostridium difficile patients were shown to be more reactive against $B$. longum extracts than that of healthy individuals (Górska et al., 2016).

In vivo models of intestinal diseases have demonstrated the potential of B. bifidum and B. animalis strains to restore immune markers and intestinal barrier in low chronic inflammation models (Philippe et al., 2011). Similarly, B. longum CECT 


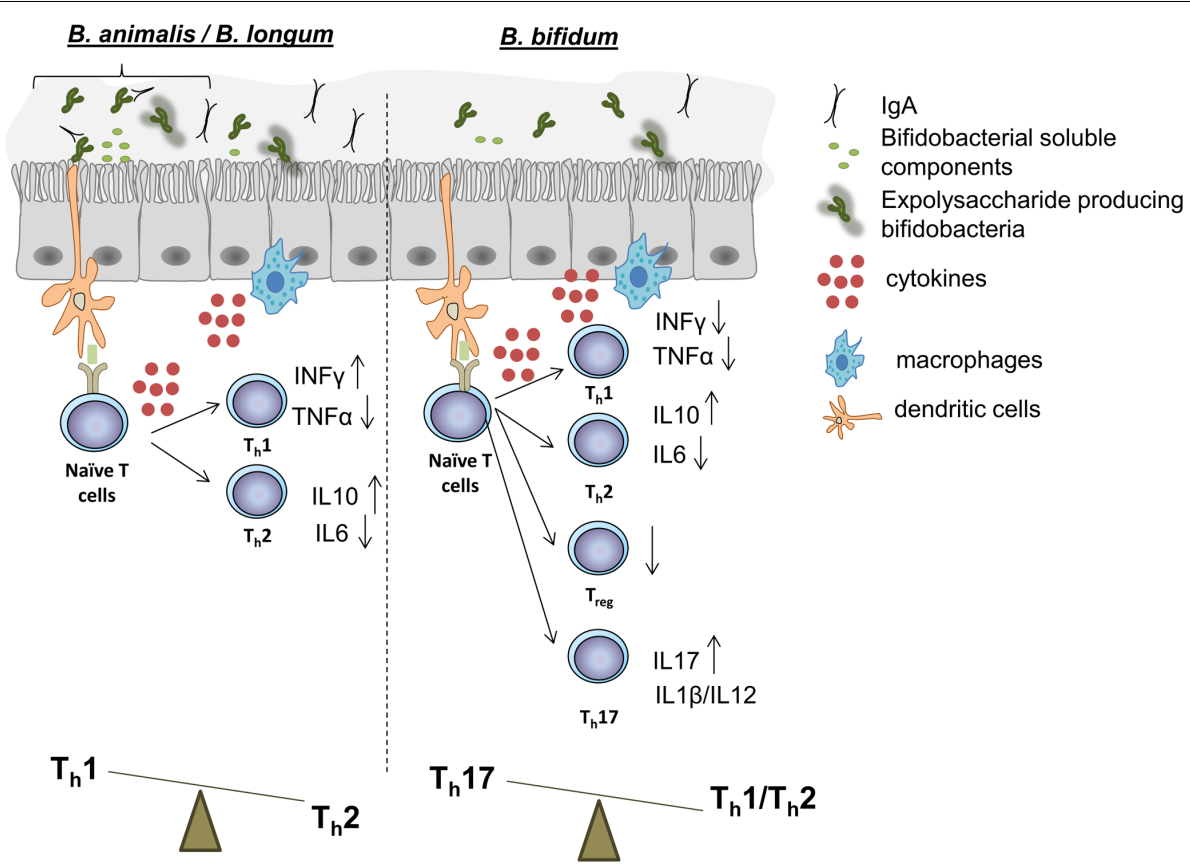

FIGURE 1 | Schematic representation of the effects on immune functions that certain strains of B. animalis, B. longum (Left), and B. bifidum (Right) have demonstrated in in vitro and in vivo experiments. Many B. animalis and B. longum strains have demonstrated capacity to promote a Th1 response, while, on the contrary, some B. bifidum strains have been revealed capable to induce a Th17 polarization. Treg responses can also be regulated by certain strains of other species. Immunomodulatory properties are strain-dependent, and further evidence is needed in order to give to each bifidobacteria species a specific immune response in the intestinal mucosa.

7347 attenuated the production of inflammatory cytokines and the $\mathrm{CD}^{+} \mathrm{T}$ cell-mediated immune response in a gliadininduced enteropathy model (Laparra et al., 2012). Other disease models, described below, have been tested in literature. In foodallergy models, a vesicle-derived protein from B. longum (Kim et al., 2016) and a B. animalis (Ezendam et al., 2008) strain, administered during lactation, exerted immunomodulatory effects. In a gut model, B. longum strain 51-A reduced inflammation (Vieira et al., 2015). Finally, in obesity models, $B$. pseudocatenulatum restored the lymphocyte-macrophage balance and $B$. adolescentis IM38 improved high-fat-diet induced colitis inhibiting NF- $\mathrm{B}$ activation (Moya-Pérez et al., 2015; Lim and Kim, 2017). Furthermore, the role of bifidobacteria in responsiveness to immunotherapy has recently been suggested. Accordingly, using tumor models in mice, Bifidobacterium administration was shown to improve tumor-specific immunity and response to therapy through augmented DC function, opening new avenues to exploit the bifidobacterial-immune dialog in the context of this disease (Sivan et al., 2015).

Finally, non-murine in vivo models, like pig models, are very attractive for the study of microbe-host interactions due to the similarities in the gastrointestinal function and development between pigs and humans. In this context, bifidobacterial administration in neonatal piglets has been shown to increase the production of intestinal IL-10 (Herfel et al., 2013), and to improve $\mathrm{B}$ and $\mathrm{T}$ cell responses following rotavirus vaccination (Vlasova et al., 2013; Kandasamy et al., 2014; Ishizuka et al., 2016). In addition, colonization with a combination of lactobacilli and bifidobacteria in non-vaccinated gnotobiotic piglets reduced the severity of rotavirus infection, while in vaccinated animals enhanced Th1 (Chattha et al., 2013). Thus, in vivo models closer to humans are valuable to study the immunomodulatory potential of certain strains, should be "particularly in the context of pig models in order to study pre-term birth and necrotizing enterocolitis (NEC)" (Oosterloo et al., 2014).

\section{Humans}

Different immunoreactive proteins from two B. longum strains have been identified in mono-colonized mice, rabbit, and human sera, revealing that the effects are strain and host specific (Górska et al., 2016) and emphasizing the need to further support in vitro immunomodulatory effects in clinical trials. A summary of human studies that focus on the immunomodulatory effects of bifidobacterial consumption in multiple disorders, in some of which gut microbial ecology dysbiosis and altered immune profiles coexist, is presented in Table $\mathbf{1}$.

\section{MOLECULAR STRUCTURES DRIVING SPECIFIC IMMUNOMODULATORY EFFECTS}

Findings from the last 10 years support the idea that bifidobacteria exert their beneficial effects on host health through the immunomodulatory action of some of their surfaceassociated molecules (Hoarau et al., 2006; Ewaschuk et al., 2008). 
TABLE 1 | Bifidobacterium role on diseases with an immunological component.

\begin{tabular}{|c|c|c|c|}
\hline $\begin{array}{l}\text { Species/strains } \\
\text { tested }\end{array}$ & Population & Observations & Reference \\
\hline \multicolumn{4}{|l|}{ Intervention studies } \\
\hline B. lactis BB12 & Healthy adults & $\begin{array}{l}\text { Four weeks administration of yogurt with the strain resulted in lower } \\
\text { expression of TLR- } 2 \text { on CD14 }{ }^{+} \mathrm{HLA}^{-D R^{+}} \text {cells and reduction in } \\
\text { TNF- } \alpha \text { secretion }\end{array}$ & Meng et al., 2017 \\
\hline B. lactis $\mathrm{Bi}-07$ & Healthy elderly adults & $\begin{array}{l}\text { Four weeks administration improved phagocytic activity of } \\
\text { monocytes and granulocytes }\end{array}$ & $\begin{array}{l}\text { Maneerat et al., } \\
2014\end{array}$ \\
\hline $\begin{array}{l}\text { B. animalis ssp. lactis } \\
\text { HN019 }\end{array}$ & $\begin{array}{l}\text { Systematic meta-analysis on four } \\
\text { clinical trials/healthy elderly subjects }\end{array}$ & $\begin{array}{l}\text { The strain supplementation resulted in increased PMN phagocytic } \\
\text { capacity and moderately increased NK cell tumoricidal activity }\end{array}$ & Miller et al., 2017 \\
\hline B. animalis LKM512 & Atopic dermatitis adult patients & $\begin{array}{l}\text { Administration into a yogurt daily for } 4 \text { weeks induced a Th1-type } \\
\text { cytokine profile }\end{array}$ & $\begin{array}{l}\text { Matsumoto et al., } \\
2007\end{array}$ \\
\hline B. lactis NCC2818 & $\begin{array}{l}\text { Seasonal allergic rhinitis to grass } \\
\text { pollen/adults }\end{array}$ & $\begin{array}{l}\text { Eight weeks probiotic administration reduced Th2-cytokines } \\
\text { secretion and CD63 expressing basophiles correlating to improved } \\
\text { symptoms }\end{array}$ & Singh et al., 2013 \\
\hline B. lactis HN019 & Metabolic syndrome patients & $\begin{array}{l}\text { Decrease in TNF } \alpha \text { and IL6 correlated to improvement in } \\
\text { cardiovascular risk markers }\end{array}$ & Bernini et al., 2016 \\
\hline $\begin{array}{l}\text { B. breve } \mathrm{BR} 03 \text { and } \\
\text { B. breve } \mathrm{B} 632\end{array}$ & Cystic fibrosis/children & $\begin{array}{l}\text { Three months administration of the two strains combination } \\
\text { reduced proinflammatory markers }\end{array}$ & $\begin{array}{l}\text { Klemenak et al., } \\
2015\end{array}$ \\
\hline $\begin{array}{l}\text { Lb. gasseri KS-13, } \\
\text { B. bifidum G9-1, and } \\
\text { B. longum MM-2 }\end{array}$ & Healthy elderly population & $\begin{array}{l}\text { Three weeks administration of probiotic mix maintained CD4+ } \\
\text { lymphocytes and resulted in a more anti-inflammatory cytokines } \\
\text { profile with increased IL-10 }\end{array}$ & Spaiser et al., 2015 \\
\hline $\begin{array}{l}\text { B. breve } \mathrm{M}-16 \mathrm{~V} \text { and } \\
\text { B. longum } \mathrm{BB} 536\end{array}$ & $\begin{array}{l}\text { Prenatal administration to pregnant } \\
\text { mothers } 1 \text { month prior delivery and } \\
\text { to the infants during } 6 \text { months }\end{array}$ & Reduced risk of developing eczema in the probiotic group & $\begin{array}{l}\text { Enomoto et al., } \\
2014\end{array}$ \\
\hline $\begin{array}{l}\text { B. longum } \mathrm{BB} 536 \text {, } \\
\text { B. infantis } \mathrm{M}-63 \text {, } \\
\text { B. breve } \mathrm{M}-16 \mathrm{~V} \text { mixture }\end{array}$ & $\begin{array}{l}\text { Seasonal allergic rhinitis and } \\
\text { intermittent asthma/children }\end{array}$ & $\begin{array}{l}\text { Improvement of symptoms following } 4 \text { weeks of probiotic } \\
\text { administration }\end{array}$ & $\begin{array}{l}\text { Miraglia Del Giudice } \\
\text { et al., } 2017\end{array}$ \\
\hline B. longum BB536 & Healthy newborns & $\begin{array}{l}\text { The number of IFN- } \gamma \text { secretion cells and the ratio of IFN- } \gamma / \mathrm{IL}-4 \\
\text { secretion cells was increased, suggesting improvement of Th1 } \\
\text { function }\end{array}$ & Wu et al., 2016 \\
\hline B. longum BB536 & $\begin{array}{l}\text { Elderly subjects receiving enteral } \\
\text { tube feeding }\end{array}$ & $\begin{array}{l}\text { Twelve weeks administration resulted in increased serum } \operatorname{lgA} \text { and } \\
\text { maintenance of NC cell activity }\end{array}$ & Akatsu et al., 2013 \\
\hline B. longum 35624 & $\begin{array}{l}\text { Patients of ulcerative colitis (UC), } \\
\text { chronic fatigue syndrome (CFS), } \\
\text { and psoriasis, as compared to } \\
\text { healthy controls }\end{array}$ & $\begin{array}{l}\text { Six to eight weeks of probiotic administration reduced CRP, TNF } \alpha \text {, } \\
\text { and IL6 in UC, CFS, and psoriasis patients }\end{array}$ & $\begin{array}{l}\text { Groeger et al., } \\
2013\end{array}$ \\
\hline B. infantis NLS & Celiac adults & $\begin{array}{l}\text { Six weeks probiotic administration reduced Paneth cells numbers } \\
\text { and expression of } \alpha \text {-defensine- } 5 \text {, as compared to patients under a } \\
\text { gluten-free diet without probiotic supplementation }\end{array}$ & $\begin{array}{l}\text { Pinto-Sánchez } \\
\text { et al., } 2017\end{array}$ \\
\hline B. longum CECT 7347 & $\begin{array}{l}\text { Children with newly diagnosed } \\
\text { coeliac disease }\end{array}$ & $\begin{array}{l}\text { Three months administration resulted in reduced peripheral CD3+ } \\
\text { lymphocytes, TNF } \alpha \text {, and slgA in stools }\end{array}$ & Olivares et al., 2014 \\
\hline \multicolumn{4}{|l|}{ Observational studies } \\
\hline B. breve & $\begin{array}{l}\text { Eczema risk in children at high risk } \\
\text { of allergic disease }\end{array}$ & $\begin{array}{l}\text { Early B. breve colonization was associated to reduced risk of } \\
\text { eczema }\end{array}$ & Ismail et al., 2016 \\
\hline $\begin{array}{l}\text { Bifidobacterium spp. } \\
\text { and } B \text {. adolescentis }\end{array}$ & Allergic asthma in adults & $\begin{array}{l}\text { Reduction in gut bifidobacterial representation and B. adolescentis } \\
\text { prevalence within the bifidobacterial group in the studied population }\end{array}$ & Hevia et al., 2016 \\
\hline B. pseudocatenulatum & Gout patients & B. pseudocatenulatum depletion in gout patients & Guo et al., 2016 \\
\hline
\end{tabular}

Summary of observational and intervention studies in humans.

This is based on the interaction of a specific bifidobacteria molecule, a MAMP, with a PRR presents on the membrane of epithelial/immune cells, which mostly configures the cellular structure of the intestinal mucosa (Sutterwala and Flavell, 2009). Although mucosa itself is differently organized, depending on the gut section considered, bifidobacteria are thought to exert their immunomodulatory activity mainly in the colon and in the distal part of the ileum, where up to $46 \%$ of the Peyer's patches are located (Van Kruiningen et al., 2002). Scientific evidence has shown the presence of immunomodulatory compounds in bifidobacteria spent medium which are released during bacterial growth (Figure 1).

\section{Proteins and Peptides}

Bifidobacterial proteins are one of the targets of human immunoglobulins, notably $\operatorname{IgA}$, which is secreted into the gut lumen in order to control the commensal microbiota populations. Up to six different extracellular proteins from the strains B. longum subsp. longum NCIMB 8809, B. bifidum LMG $11041^{\mathrm{T}}$, and $B$. animalis subsp. lactis IPLA 4549 were recognized 
by pooled sera from healthy individuals, or Inflammatory Bowel Disease (IBD) patients (Hevia et al., 2014). Perhaps the best known example of an immunomodulatory protein is the extracellular serpin secreted by B. longum subsp. longum. Serpin stands for serine protease inhibitor and includes different families that share the ability to bind and irreversibly inactivate proteases. The gene coding for serpin is not widely distributed among the genus Bifidobacterium, being present in up to nine species so far (Turroni et al., 2010a). More precisely, the targets of serpin secreted by $B$. longum are two important pro-inflammatory proteases: human neutrophil and pancreatic elastases (Ivanov et al., 2006), proteases that have been shown to induce the serpin gene through a two-component regulatory system (AlvarezMartin et al., 2012). Limiting the local action of these proteases suggests a role of bifidobacteria in the maintenance of gut homeostasis.

Other well-known protein structures with an immunomodulatory action are pili, which self-assemble on the bifidobacteria surface in the form of filaments and have a primary function of adherence to the intestinal surface (Turroni et al., 2014). Lower levels of IL10 and higher levels of TNF $\alpha$ were detected in the murine cecum mucosa as a response to the presence of a Lactococcus lactis strain, genetically modified for producing $B$. bifidum pili. This response was not observed in the wild-type strain, suggesting a specific interaction of these structures with the gastrointestinal mucosa (Turroni et al., 2013). Another protein with an immunomodulatory effect is the peptidoglycan hydrolase TgaA, a surface-associated protein in $B$. bifidum, which was shown to induce IL2 production in monocyte-derived dendritic cell (MoDC), the key cytokine in $\mathrm{T}_{\text {reg }}$ cell expansion (Zelante et al., 2012; Guglielmetti et al., 2014). Finally, our own work has revealed the presence of immunomodulatory peptides encrypted in the sequences of bifidobacteria proteins. In this sense, a peptide contained within the sequence of the protein translocase subunit SecA of B. longum DJ010A triggered a marked Th17 response when incubated with human PBMCs (Hidalgo-Cantabrana et al., 2017b).

\section{EPSs}

EPSs are carbohydrate polymers that are synthesized and exhibited in the bifidobacterial surface (Hidalgo-Cantabrana et al., 2014). Although the exact molecular mechanisms have not been described so far, EPSs have a great impact on the host immune function (Hidalgo-cantabrana et al., 2012). In a murine model, the EPS-producing strain B. breve UCC2003 was associated with increases in the mucosal levels of the proinflammatory IL12, INF $\gamma$, and TNF $\alpha$ which turned out to protect against Citrobacter infection (Fanning et al., 2012). Murine J77A.1 macrophages challenged with the EPS produced by strain B. longum BCRC 14634 increased the production of the antiinflammatory cytokine IL10 when compared to basal conditions, and when challenged with lipopolysaccharide, the presence of the EPS was linked to lower levels of the pro-inflammatory cytokine $\mathrm{TNF} \alpha$ (Wu et al., 2010). It is noteworthy that the rhamnose-rich, high-molecular weight EPS isolated from the strain $B$. animalis subsp. lactis IPLA-R1 was able to increase IL10 production in a PBMC model and to decrease the TNF $\alpha$ production in human colonic biopsies (Hidalgo-Cantabrana et al., 2015). Moreover, the administration of strain IPLA-R1 to Wistar rats was associated with higher serum levels of TGF $\beta$ and lower serum levels of the pro-inflammatory interleukin IL6 (Salazar et al., 2014).

EPS produced by specific bifidobacteria strains have been shown as molecules able to prevent exacerbated proinflammatory responses. B. longum subsp. longum 35624 is a strain which has shown clinical efficacy in Irritable Bowel Syndrome, a human condition cursing with chronic mucosal inflammation (Altmann et al., 2016). The antiinflammatory effects elicited by this strain were shown to rely in its surface-associated EPS, which prevented expansion of the pro-inflammatory Th17 response compared to an exopolysaccharide-negative mutant derivative (Schiavi et al., 2016).

Finally, recent data on a mouse model of pathological cell shedding, EPS from B. breve UCC2003 appeared to confer protective effect through MyD88-dependent signaling (Hughes et al., 2017). Diversity of gene clusters responsible for EPS biosynthesis is high among bifidobacterial species/strains (not to mention variations in the level of EPS production) and this diversity may hold tremendous potential for strain-specific immune responses.

\section{DNA}

Bifidobacteria possess genomes with high $\mathrm{G}+\mathrm{C}$ proportions, and un-methylated $\mathrm{CpG}$ motifs derived from them can interact with the TLR 9 present on immune cells. Several publications have reported on the immunomodulatory activity of bifidobacterial DNA. CpG motifs have in one case been linked to a promotion of the $T_{h} 1$ response, dedicated to fight intracellular pathogens such as viruses (Ménard et al., 2010). Another work described an oligodeoxynucleotide derived from the B. longum BB536 strain able to inhibit anti-ovalbumin-IgE titres in a murine model of type-I allergic response after ovalbumin injection (Takahashi et al., 2006).

\section{BIFIDOBACTERIAL METABOLISM TRIGGERS CROSS-FEEDING MECHANISMS THAT MAINTAIN IMMUNE HOMEOSTASIS IN THE GUT}

Many efforts are currently being pursued to understand the metabolic fluxes within the gut ecosystem among bifidobacteria, other members of the gut microbiota and the human host (Hidalgo-Cantabrana et al., 2017a). A major metabolic contribution elicited by bifidobacteria from their host is represented by the breakdown of non-digestible, diet-derived glycans, and carbohydrates provided by the host known as host-derived glycans [mucins and human milk oligosaccharides (HMOs)] (Milani et al., 2015). Mucin is a host-produced glycan that constitutes one of the main barriers covering the gastrointestinal mucosa (Tailford et al., 2015). Among bifidobacteria, only members of B. bifidum species have been shown to efficiently metabolize mucin 
(Ruas-Madiedo et al., 2008; Turroni et al., 2010b; Ruiz et al., 2011). HMOs are present in high concentrations in human colostrum and breast milk. Bifidobacteria, which dominate during early life, are among the best described gut bacteria with the ability to utilize HMOs. Several species possess glycosyl hydrolases that cleave specific linkages within the HMO molecules, the best characterized being those synthesized by $B$. bifidum (Ruiz et al., 2016). HMOs are preferentially fermented by $B$. bifidum and B. longum species which, together with $B$. breve, are the most abundant in breast-fed infant gut microbiota (Sela and Mills, 2010). Thus, the ability of these species to utilize these otherwise indigestible carbohydrates explains their abundance in breast-fed neonates (Zivkovic et al., 2011).

Metabolic cross-feeding mechanisms in the gut are commonly exploited by primary microbial degraders like bifidobacteria which, thanks to partial extracellular hydrolysis of specific complex carbohydrates (e.g., host-produced glycans), provide monosaccharides, oligosaccharides, or metabolites for other microbial gut inhabitants (De Vuyst and Leroy, 2011). As an example, B. bifidum PRL2010 is a strain specialized in the extracellular breakdown of host-glycans and, thus, in the release of simple sugars that can be utilized by other members of the (bifido)bacterial community (Turroni et al., 2016). The subsequent fermentative metabolism of these carbohydrates generates end-metabolites, such as acetate and lactate, which are the main end-products of the bifidobacteria catabolism. Acetate released in the gut by bifidobacteria is used as substrates for other microbial gut fermenters, mainly butyrate and propionate producers (Flint et al., 2015). The production of these two major short-chain fatty acid metabolites have been shown to have anti-inflammatory effects, and promotes and regulates the pool of colonic $\mathrm{T}_{\text {reg }}$ cells (Arpaia et al., 2013; Smith et al., 2013). By inhibiting histone deacetylase activity in $\mathrm{DC}$ and $\mathrm{T}$ cells, butyrate acts in the differentiation of $\mathrm{T}_{\text {reg }}$ cells, increasing the expression of the $\mathrm{T}_{\text {reg }}$ marker FoxP3 (Furusawa et al., 2013). Signalization has been proposed to be mediated by the butyrate receptors in epithelial and immune cells named FFAR3 (free fatty acid

\section{REFERENCES}

Ahmed, K., Tunaru, S., and Offermanns, S. (2009). GPR109A, GPR109B and GPR81, a family of hydroxy-carboxylic acid receptors. Trends. Pharmacol. Sci. 30, 557-562. doi: 10.1016/j.tips.2009.09.001

Akatsu, H., Iwabuchi, N., Xiao, J., Matsuyama, Z., Kurihara, R., Okuda, K., et al. (2013). Clinical effects of probiotic Bifidobacterium longum BB536 on immune function and intestinal microbiota in elderly patients receiving enteral tube feeding. J. Parenter Enteral Nutr. 37, 631-640. doi: 10.1177/0148607112467819

Altmann, F., Kosma, P., O'Callaghan, A., Leahy, S., Bottacini, F., Molloy, E., et al. (2016). Genome analysis and characterisation of the exopolysaccharide produced by Bifidobacterium longum subsp. longum $35624^{\mathrm{TM}}$. PLOS ONE 11:e0162983. doi: 10.1371/journal.pone.0162983

Alvarez-Martin, P., O’Connell Motherway, M., Turroni, F., Foroni, E., Ventura, M., and van Sinderen, D. (2012). A two-component regulatory system controls autoregulated serpin expression in Bifidobacterium breve UCC2003. Appl. Environ. Microbiol. 78, 7032-7041. doi: 10.1128/AEM.01776-12

Arboleya, S., Bahrami, B., Macfarlane, S., Gueimonde, M., Macfarlane, G. T., and de los Reyes-Gavilán, C. G. (2015). Production of immune response mediators receptor 3) and GPR109A (Ahmed et al., 2009; Remely et al., 2014).

\section{CONCLUDING REMARKS}

Bifidobacterial cells, their subcellular fractions, or specific molecules produced by these microorganisms, hold an important potential to trigger immunomodulatory responses involved in the maintenance of our healthy physiological state. However, these responses are poorly understood and need for more research on how this molecular communication between bifidobacteria and host cells is performed. Additionally, the increasing knowledge on the role played by different gut microbiota members, and the understanding of the cross-talk and cross-feeding interaction processes between bifidobacteria, the host, and the surrounding network of intestinal microbes, should facilitate the synergistic use of different intestinal microorganisms to modulate the immunological and inflammatory processes in a microbial dependent way.

\section{AUTHOR CONTRIBUTIONS}

$\mathrm{AM}$ and BS designed the structure of the mini-review. LR, SD, PR-M, BS, and AM wrote the manuscript and drafted the first version of the manuscript. All authors reviewed the final version of the manuscript.

\section{ACKNOWLEDGMENTS}

LR is a postdoctoral researcher supported by the Juan de la Cierva Postdoctoral Trainee Program of the Spanish Ministry of Economy and Competitiveness (MINECO; IJCI-2015-23196). BS and AM thanks MINECO for the funding of the project AGL2016-78311-R and PR-M for the project AGL2015-64901-R. $\mathrm{SD}$ is supported by a research contract associated to the project BIO2014-55019-JIN from the Spanish "Plan Estatal de I+D+i".

by HT-29 intestinal cell-lines in the presence of Bifidobacterium-treated infant microbiota. Benef. Microbes 6, 543-552. doi: 10.3920/BM2014.0111

Arboleya, S., Binetti, A., Salazar, N., Fernandez, N., Solis, G., HernandezBarranco, A., et al. (2012). Establishment and development of intestinal microbiota in preterm neonates. FEMS Microbiol. Ecol. 79, 763-772. doi: 10. 1111/j.1574-6941.2011.01261.x [Epub. 2011 Dec. 15].

Arpaia, N., Campbell, C., Fan, X., Dikiy, S., van der Veeken, J., deRoos, P., et al. (2013). Metabolites produced by commensal bacteria promote peripheral regulatory T-cell generation. Nature 504, 451-455. doi: 10.1038/nature12726

Bahrami, B., Macfarlane, S., and Macfarlane, G. T. (2011). Induction of cytokine formation by human intestinal bacteria in gut epithelial cell lines. J. Appl. Microbiol. 110, 353-363. doi: 10.1111/j.1365-2672.2010.04889.x

Bernini, L. J., Simão, A. N. C., Alfieri, D. F., Lozovoy, M. A. B., Mari, N. L., de Souza, C. H., et al. (2016). Beneficial effects of Bifidobacterium lactis on lipid profile and cytokines in patients with metabolic syndrome: a randomized trial. Effects of probiotics on metabolic syndrome. Nutrition 32, 716-719. doi: 10.1016/j.nut.2015.11.001

Chattha, K. S., Vlasova, A. N., Kandasamy, S., Rajashekara, G., and Saif, L. J. (2013). Divergent immunomodulating effects of probiotics on $\mathrm{T}$ cell responses to oral 
attenuated human rotavirus vaccine and virulent human rotavirus infection in a neonatal gnotobiotic piglet disease model. J. Immunol. 191, 2446-2456. doi: 10.4049/jimmunol.1300678

Chichlowski, M., De Lartigue, G., German, J. B., Raybould, H. E., and Mills, D. A. (2012). Bifidobacteria isolated from infants and cultured on human milk oligosaccharides affect intestinal epithelial function. J. Pediatr. Gastroenterol. Nutr. 55, 321-327. doi: 10.1097/MPG.0b013e31824fb899

Davis, M. Y., Zhang, H., Brannan, L. E., Carman, R. J., and Boone, J. H. (2016). Rapid change of fecal microbiome and disappearance of Clostridium difficile in a colonized infant after transition from breast milk to cow milk. Microbiome 4:53. doi: 10.1186/s40168-016-0198-6

De Vuyst, L., and Leroy, F. (2011). Cross-feeding between bifidobacteria and butyrate-producing colon bacteria explains bifidobacterial competitiveness, butyrate production, and gas production. Int. J. Food Microbiol. 149, 73-80. doi: 10.1016/j.ijfoodmicro.2011.03.003

Duell, B. J., Cripps, A. W., Mark, A., Schembri, M. A., and Ulett, G. C. (2011). Epithelial cell coculture models for studying infectious diseases: benefits and limitations. J. Biomed. Biotechnol. 2011:852419. doi: 10.1155/2011/ 852419

Enomoto, T., Sowa, M., Nishimori, K., Shimazu, S., Yoshida, A., Yamada, K., et al. (2014). Effects of bifidobacterial supplementation to pregnant women and infants in the prevention of allergy development in infants and on fecal microbiota. Allergol. Int. 63, 575-585. doi: 10.2332/allergolint.13-OA-0683

Ewaschuk, J. B., Diaz, H., Meddings, L., Diederichs, B., Dmytrash, A., Backer, J., et al. (2008). Secreted bioactive factors from Bifidobacterium infantis enhance epithelial cell barrier function. Am. J. Physiol. Gastrointest. Liver Physiol. 295, G1025-G1034. doi: 10.1152/ajpgi.90227.2008

Ezendam, J., de Klerk, A., Gremmer, E. R., and van Loveren, H. (2008). Effects of Bifidobacterium animalis administered during lactation on allergic and autoimmune responses in rodents. Clin. Exp. Immunol. 154, 424-431. doi: 10.1111/j.1365-2249.2008.03788.x

Fanning, S., Hall, L. J., Cronin, M., Zomer, A., MacSharry, J., Goulding, D., et al. (2012). Bifidobacterial surface-exopolysaccharide facilitates commensal-host interaction through immune modulation and pathogen protection. Proc. Natl. Acad. Sci. U.S.A. 109, 2108-2113. doi: 10.1073/pnas.1115621109

Flint, H. J., Duncan, S. H., Scott, K. P., and Louis, P. (2015). Links between diet, gut microbiota composition and gut metabolism. Proc. Nutr. Soc. 74, 13-22. doi: 10.1017/S0029665114001463

Fujimura, K. E., Sitarik, A. R., Havstad, S., Lin, D. L., Levan, S., Fadrosh, D., et al. (2016). Neonatal gut microbiota associates with childhood multisensitized atopy and T cell differentiation. Nature Med. 22, 1187-1191. doi: 10.1038/ nm.4176

Furusawa, Y., Obata, Y., Fukuda, S., Endo, T., Nakato, G., Takahashi, D., et al. (2013). Commensal microbe-derived butyrate induces the differentiation of colonic regulatory T cells. Nature 504, 446-450. doi: 10.1038/nature12721

Górska, S., Dylus, E., Rudawska, A., Brzozowska, E., Srutkova, D., Schwarzer, M., et al. (2016). Immunoreactive Proteins of Bifidobacterium longum ssp. longum CCM 7952 and Bifidobacterium longum ssp. longum CCDM 372 Identified by Gnotobiotic Mono-Colonized Mice Sera, Immune Rabbit Sera and Nonimmune Human Sera. Front. Microbiol. 7:1537. doi: 10.3389/fmicb.2016.01537

Groeger, D., O’Mahony, L., Murphy, E. F., Bourke, J. F., Dinan, T. G., Kiely, B., et al. (2013). Bifidobacterium infantis 35624 modulates host inflammatory processes beyond the gut. Gut Microbes 4, 325-339. doi: 10.4161/gmic.25487

Guglielmetti, S., Zanoni, I., Balzaretti, S., Miriani, M., Taverniti, V., De Noni, I., et al. (2014). Murein lytic enzyme TgaA of Bifidobacterium bifidum MIMBb75 modulates dendritic cell maturation through its cysteine- and histidinedependent amidohydrolase/peptidase (CHAP) amidase domain. Appl. Environ. Microbiol. 80, 5170-5177. doi: 10.1128/AEM.00761-14

Guo, Z., Zhang, J., Wang, Z., Ang, K. Y., Huang, S., Hou, Q., et al. (2016). Intestinal microbiota distinguish gout patients from healthy humans. Sci. Rep. 6:20602. doi: 10.1038/srep20602

He, F., Morita, H., Ouwehand, A. C., Hosoda, M., Hiramatsu, M., Kurisaki, J., et al. (2002). Stimulation of the secretion of pro-inflammatory cytokines by bifidobacterium strains. Microbiol. Immunol. 46, 781-785. doi: 10.1111/j.13480421.2002.tb02765.x

Herfel, T. M., Jacobi, S. K., Lin, X., Jouni, Z. E., Chichlowski, M., Stahl, C. H., et al. (2013). Dietary supplementation of Bifidobacterium longum strain AH1206 increases its cecal abundance and elevates intestinal interleukin-10 expression in the neonatal piglet. Food Chem. Toxicol. 60, 116-122. doi: 10.1016/j.fct.2013. 07.020

Hevia, A., López, P., Suárez, A., Jacquot, C., Urdaci, M. C., Margolles, A., et al. (2014). Association of levels of antibodies from patients with inflammatory bowel disease with extracellular proteins of food and probiotic bacteria. Biomed Res. Int. 2014:351204. doi: 10.1155/2014/351204

Hevia, A., Milani, C., López, P., Donado, C. D., Cuervo, A., González, S., et al. (2016). Allergic patients with long-term asthma display low levels of Bifidobacterium adolescentis. PLOS ONE 11:e0147809. doi: 10.1371/journal. pone.0147809

Hidalgo-cantabrana, C., Arboleya, S., Sánchez, B., Gueimonde, M., de los ReyesGavilán, C. G., Margolles, A., et al. (2012). "Intestinal Microbiota as a source of probiotic Bifidobacterium strains: challenges and opportunities for the development of functional foods," in Beneficial Microbes in Fermented and Functional Foods, eds R. Rai and J. A. Bai (Boca Raton, FL: CRC Press).

Hidalgo-Cantabrana, C., Delgado, S., Ruiz, L., Ruas-Madiedo, P., Sánchez, B., and Margolles, A. (2017a). Bifidobacteria and their health-promoting effects. Microbiol. Spectr. 5:BAD-0010-2016. doi: 10.1128/microbiolspec.BAD-00102016

Hidalgo-Cantabrana, C., Moro-García, M. A., Blanco-Míguez, A., FernándezRiverola, F., Lourenço, A., Alonso-Arias, R., et al. (2017b). In silico screening of the human gut metaproteome identifies Th17-promoting peptides encrypted in proteins of commensal bacteria. Front. Microbiol. 8:1726. doi: 10.3389/fmicb. 2017.01726

Hidalgo-Cantabrana, C., Sánchez, B., Álvarez-Martín, P., López, P., MartínezÁlvarez, N., Delley, M., et al. (2015). A single mutation in the gene responsible for the mucoid phenotype of Bifidobacterium animalis subsp. lactis confers surface and functional characteristics. Appl. Environ. Microbiol. 81, 7960-7968. doi: 10.1128/AEM.02095-15

Hidalgo-Cantabrana, C., Sánchez, B., Milani, C., Ventura, M., Margolles, A., and Ruas-Madiedo, P. (2014). Genomic overview and biological functions of exopolysaccharide biosynthesis in Bifidobacterium spp. Appl. Environ. Microbiol. 80, 9-18. doi: 10.1128/AEM.02977-13

Hill, C. J., Lynch, D. B., Murphy, K., Ulaszewska, M., Jeffery, I. B., O’Shea, C., et al. (2017). Evolution of gut microbiota composition from birth to 24 weeks in the INFANTMET cohort. Microbiome 5:4. doi: 10.1186/s40168-0160213-y

Hoarau, C., Lagaraine, C., Martin, L., Velge-Roussel, F., and Lebranchu, Y. (2006). Supernatant of Bifidobacterium breve induces dendritic cell maturation, activation, and survival through a Toll-like receptor 2 pathway. J. Allergy Clin. Immunol. 117, 696-702. doi: 10.1016/j.jaci.2005.10.043

Hoarau, C., Martin, L., Faugaret, D., Baron, C., Dauba, A., Aubert-Jacquin, C., et al. (2008). Supernatant from Bifidobacterium differentially modulates transduction signaling pathways for biological functions of human dendritic cells. PLOS ONE 3:e2753. doi: 10.1371/journal.pone.0002753

Hughes, K. R., Harnisch, L. C., Alcon-Giner, C., Mitra, S., Wright, C. J., Ketskemety, J., et al. (2017). Bifidobacterium breve reduces apoptotic epithelial cell shedding in an exopolysaccharide and MyD88-dependent manner. Open Biol. 7:160155. doi: 10.1098/rsob.160155

Ishizuka, T., Kanmani, P., Kobayashi, H., Miyazaki, A., Soma, J., Suda, Y., et al. (2016). Immunobiotic bifidobacteria strains modulate rotavirus immune response in porcine intestinal epitheliocytes via pattern recognition receptor signaling. PLOS ONE 11:e0152416. doi: 10.1371/journal.pone.0152416

Ismail, I. H., Boyle, R. J., Licciardi, P. V., Oppedisano, F., Lahtinen, S., RobinsBrowne, R. M., et al. (2016). Early gut colonization by Bifidobacterium breve and $B$. catenulatum differentially modulates eczema risk in children at high risk of developing allergic disease. Pediatr. Allergy Immunol. 27, 838-846. doi: 10.1111/pai.12646

Ivanov, D., Emonet, C., Foata, F., Affolter, M., Delley, M., Fisseha, M., et al. (2006). A serpin from the gut bacterium Bifidobacterium longum inhibits eukaryotic elastase-like serine proteases. J. Biol. Chem. 281, 17246-17252. doi: 10.1074/jbc. M601678200

Kalliomaki, M., Kirjavainen, P., Eerola, E., Kero, P., Salminen, S., and Isolauri, E. (2001). Distinct patterns of neonatal gut microflora in infants in whom atopy was and was not developing. J. Allergy Clin. Immunol. 107, 129-134. doi: 10. 1067/mai.2001.111237

Kandasamy, S., Chattha, K. S., Vlasova, A. N., Rajashekara, G., and Saif, L. J. (2014). Lactobacilli and Bifidobacteria enhance mucosal B cell responses and 
differentially modulate systemic antibody responses to an oral human rotavirus vaccine in a neonatal gnotobiotic pig disease model. Gut Microbes 5, 639-651. doi: 10.4161/19490976.2014.969972

Khokhlova, E. V., Smeianov, V. V., Efimov, B. A., Kafarskaia, L. I., Pavlova, S. I., and Shkoporov, A. N. (2012). Anti-inflammatory properties of intestinal Bifidobacterium strains isolated from healthy infants. Microbiol. Immunol. 56, 27-39. doi: 10.1111/j.1348-0421.2011.00398.x

Kim, J.-H., Jeun, E.-J., Hong, C.-P., Kim, S.-H., Jang, M. S., Lee, E.-J., et al. (2016). Extracellular vesicle derived protein from Bifidobacterium longum alleviates food allergy through mast cell suppression. J. Allergy Clin. Immunol. 137, 507-516. doi: 10.1016/j.jaci.2015.08.016

Klemenak, M., Dolinšek, J., Langerholc, T., Di Gioia, D., and Mičetić-Turk, D. (2015). Administration of Bifidobacterium breve decreases the production of TNF- $\alpha$ in children with celiac disease. Dig. Dis. Sci. 60, 3386-3392. doi: 10.1007/ s10620-015-3769-7

Kobayashi, H., Kanmani, P., Ishizuka, T., Miyazaki, A., Soma, J., Albarracin, L., et al. (2017). Development of an in vitro immunobiotic evaluation system against rotavirus infection in bovine intestinal epitheliocytes. Benef. Microbes 8, 309-321. doi: 10.3920/BM2016.0155

Laparra, J. M., Olivares, M., Gallina, O., and Sanz, Y. (2012). Bifidobacterium longum CECT 7347 modulates immune responses in a gliadin-induced enteropathy animal model. PLOS ONE 7:e30744. doi: 10.1371/journal.pone. 0030744

Lee, D.-K., Kim, M.-J., Ham, J.-W., An, H.-M., Cha, M.-K., Lee, S.-W., et al. (2012). In Vitro evaluation of antibacterial activities and anti-inflammatory effects of Bifidobacterium spp. addressing acne vulgaris. Arch. Pharm. Res. 35, 1065-1071. doi: 10.1007/s12272-012-0614-9

Lim, S.-M., and Kim, D.-H. (2017). Bifidobacterium adolescentis IM38 ameliorates high-fat diet-induced colitis in mice by inhibiting NF- $\kappa \mathrm{B}$ activation and lipopolysaccharide production by gut microbiota. Nutr. Res. 41, 86-96. doi: 10.1016/j.nutres.2017.04.003

Liu, Y., Gibson, G. R., and Walton, G. E. (2016). An in vitro approach to study effects of prebiotics and probiotics on the faecal microbiota and selected immune parameters relevant to the elderly. PLOS ONE 11:e0162604. doi: 10.1371/journal.pone.0162604

López, P., Gueimonde, M., Margolles, A., and Suárez, A. (2010). Distinct Bifidobacterium strains drive different immune responses in vitro. Int. J. Food Microbiol. 138, 157-165. doi: 10.1016/j.ijfoodmicro.2009.12.023

Luongo, D., Treppiccione, L., Sorrentino, A., Ferrocino, I., Turroni, S., Gatti, M., et al. (2017). Immune-modulating effects in mouse dendritic cells of lactobacilli and bifidobacteria isolated from individuals following omnivorous, vegetarian and vegan diets. Cytokine 97, 141-148. doi: 10.1016/j.cyto.2017. 06.007

Maneerat, S., Lehtinen, M. J., Childs, C. E., Forssten, S. D., Alhoniemi, E., Tiphaine, M., et al. (2014). Consumption of Bifidobacterium lactis Bi-07 by healthy elderly adults enhances phagocytic activity of monocytes and granulocytes. J. Nutr. Sci. 2, e44. doi: 10.1017/jns.2013.31

Matsumoto, M., Aranami, A., Ishige, A., Watanabe, K., and Benno, Y. (2007). LKM512 yogurt consumption improves the intestinal environment and induces the T-helper type 1 cytokine in adult patients with intractable atopic dermatitis. Clin. Exp. Allergy 37, 358-370. doi: 10.1111/j.1365-2222.2007. 02642.x

Medina, M., Izquierdo, E., Ennahar, S., and Sanz, Y. (2007). Differential immunomodulatory properties of Bifidobacterium logum strains: relevance to probiotic selection and clinical applications. Clin. Exp. Immunol. 150, 531-538. doi: $10.1111 / j .1365-2249.2007 .03522 . x$

Ménard, O., Gafa, V., Kapel, N., Rodriguez, B., Butel, M. J., and Waligora-Dupriet, A. J. (2010). Characterization of immunostimulatory CpG-rich sequences from different Bifidobacterium species. Appl. Environ. Microbiol. 76, 2846-2855. doi: 10.1128/AEM.01714-09

Meng, H., Ba, Z., Lee, Y., Peng, J., Lin, J., Fleming, J. A., et al. (2017). Consumption of Bifidobacterium animalis subsp. lactis BB-12 in yogurt reduced expression of TLR-2 on peripheral blood-derived monocytes and pro-inflammatory cytokine secretion in young adults. Eur. J. Nutr. 56, 649-661. doi: 10.1007/s00394-015$1109-5$

Milani, C., Lugli, G. A., Duranti, S., Turroni, F., Mancabelli, L., Ferrario, C., et al. (2015). Bifidobacteria exhibit social behavior through carbohydrate resource sharing in the gut. Sci. Rep. 5:15782. doi: 10.1038/srep15782
Miller, L. E., Lehtoranta, L., and Lehtinen, M. J. (2017). The Effect of Bifidobacterium animalis ssp. lactis HN019 on cellular immune function in healthy elderly subjects: systematic review and meta-analysis. Nutrients 9:E191. doi: $10.3390 /$ nu9030191

Miraglia Del Giudice, M., Indolfi, C., Capasso, M., Maiello, N., Decimo, F., and Ciprandi, G. (2017). Bifidobacterium mixture (B longum BB536, B infantis M63 , B breve $\mathrm{M}-16 \mathrm{~V}$ ) treatment in children with seasonal allergic rhinitis and intermittent asthma. Ital. J. Pediatr. 43:25. doi: 10.1186/s13052-017-0340-5

Mokrozub, V. V., Lazarenko, L. M., Sichel, L. M., Babenko, L. P., Lytvyn, P. M., Demchenko, O. M., et al. (2015). The role of beneficial bacteria wall elasticity in regulating innate immune response. EPMA J. 6, 13. doi: 10.1186/s13167-0150035-1

Mouni, F., Aissi, E., Hernández, J., Gorocica, P., Bouquelet, S., Zenteno, E., et al. (2009). Effect of Bifidobacterium bifidum DSM 20082 cytoplasmic fraction on human immune cells. Immunol. Invest. 38, 104-115. doi: 10.1080/ 08820130802608303

Moya-Pérez, A., Neef, A., and Sanz, Y. (2015). Bifidobacterium pseudocatenulatum CECT 7765 reduces obesity-associated inflammation by restoring the lymphocyte-macrophage balance and gut microbiota structure in high-fat dietfed mice. PLOS ONE 10:e0126976. doi: 10.1371/journal.pone.0126976

Nicola, S., Amoruso, A., Deidda, F., Pane, M., Allesina, S., Mogna, L., et al. (2016). Searching for the perfect homeostasis: five strains of Bifidobacterium longum from centenarians have a similar behavior in the production of cytokines. J. Clin. Gastroenterol. 50, S126-S130. doi: 10.1097/MCG.0000000000000678

Noel, G., Baetz, N. W., Staab, J. F., Donowitz, M., Kovbasnjuk, O., Pasetti, M. P., et al. (2017). A primary human macrophage-enteroid co-culture model to investigate mucosal gut physiology and host-pathogen interactions. Sci. Rep. 7:45270. doi: 10.1038/srep45270

Olivares, M., Castillejo, G., Varea, V., and Sanz, Y. (2014). Double-blind, randomised, placebo-controlled intervention trial to evaluate the effects of Bifidobacterium longum CECT 7347 in children with newly diagnosed coeliac disease. Br. J. Nutr. 112, 30-40. doi: 10.1017/S0007114514000609

Oosterloo, B. C., Premkumar, M., Stoll, B., Olutoye, O., Thymann, T., Sangild, P. T., et al. (2014). Dual purpose use of preterm piglets as a model of pediatric GI disease. Vet. Immunol. Immunopathol. 159, 156-165. doi: 10.1016/j.vetimm. 2014.02.012

Philippe, D., Heupel, E., Blum-Sperisen, S., and Riedel, C. U. (2011). Treatment with Bifidobacterium bifidum 17 partially protects mice from Th1-driven inflammation in a chemically induced model of colitis. Int. J. Food Microbiol. 149, 45-49. doi: 10.1016/j.ijfoodmicro.2010.12.020

Pinto-Sánchez, M. I., Smecuol, E. C., Temprano, M. P., Sugai, E., González, A., Moreno, M. L., et al. (2017). Bifidobacterium infantis NLS super strain reduces the expression of $\alpha$-defensin-5, a marker of innate immunity, in the mucosa of active celiac disease patients. J. Clin. Gastroenterol. 51, 814-817. doi: 10.1097/ MCG.0000000000000687

Pozo-Rubio, T., Mujico, J. R., Marcos, A., Puertollano, E., Nadal, I., Sanz, Y., et al. (2011). Immunostimulatory effect of faecal Bifidobacterium species of breastfed and formula-fed infants in a peripheral blood mononuclear cell/Caco-2 coculture system. Br. J. Nutr. 106, 1216-1223. doi: 10.1017/S0007114511001656

Remely, M., Aumueller, E., Merold, C., Dworzak, S., Hippe, B., Zanner, J., et al. (2014). Effects of short chain fatty acid producing bacteria on epigenetic regulation of FFAR3 in type 2 diabetes and obesity. Gene 537, 85-92. doi: 10.1016/j.gene.2013.11.081

Ruas-Madiedo, P., Gueimonde, M., Fernández-García, M., de los Reyes-Gavilán, C. G., and Margolles, A. (2008). Mucin degradation by Bifidobacterium strains isolated from the human intestinal microbiota. Appl. Environ. Microbiol. 74, 1936-1940. doi: 10.1128/AEM.02509-07

Ruiz, L., Delgado, S., Ruas-Madiedo, P., Margolles, A., and Sánchez, B. (2016). Proteinaceous molecules mediating Bifidobacterium-host interactions. Front. Microbiol. 7:1193. doi: 10.3389/fmicb.2016.01193

Ruiz, L., Gueimonde, M., Coute, Y., Salminen, S., Sánchez, J. C., de los ReyesGavilán, C. G., et al. (2011). Evaluation of the ability of Bifidobacterium longum to metabolize human intestinal mucus. FEMS Microbiol. Lett. 314, 125-130. doi: 10.1111/j.1574-6968.2010.02159.x

Salazar, N., López, P., Garrido, P., Moran, J., Cabello, E., Gueimonde, M., et al. (2014). Immune modulating capability of two exopolysaccharide-producing Bifidobacterium strains in a wistar rat model. Biomed Res. Int. 2014:106290. doi: $10.1155 / 2014 / 106290$ 
Sánchez, B., González-Rodriguez, I., Arboleya, S., López, P., Suárez, A., RuasMadiedo, P., et al. (2015). The effects of Bifidobacterium breve on immune mediators and proteome of HT29 cells monolayers. Biomed. Res. Int. 2015:479140. doi: 10.1155/2015/479140

Schiavi, E., Gleinser, M., Molloy, E., Groeger, D., Frei, R., Ferstl, R., et al. (2016). The surface-associated exopolysaccharide of Bifidobacterium longum 35624 plays an essential role in dampening host proinflammatory responses and repressing local TH17 responses. Appl. Environ. Microbiol. 82, 7185-7196. doi: 10.1128/ AEM.02238-16

Sela, D. A., and Mills, D. A. (2010). Nursing our microbiota: molecular linkages between bifidobacteria and milk oligosaccharides. Trends Microbiol. 18, 298-307. doi: 10.1016/j.tim.2010.03.008

Singh, A., Hacini-Rachinel, F., Gosoniu, M. L., Bourdeau, T., Holvoet, S., Doucet-Ladeveze, R., et al. (2013). Immune-modulatory effect of probiotic Bifidobacterium lactis NCC2818 in individuals suffering from seasonal allergic rhinitis to grass pollen: an exploratory, randomized, placebo-controlled clinical trial. Eur. J. Clin. Nutr. 67, 161-167. doi: 10.1038/ejcn.2012.197

Sivan, A., Corrales, L., Hubert, N., Williams, J. B., Aquino-Michaels, K., Earley, Z. M., et al. (2015). Commensal Bifidobacterium promotes antitumor immunity and facilitates anti-PD-L1 efficacy. Science 350, 1084-1089. doi: 10.1126/ science.aac 4255

Smith, P. M., Howitt, M. R., Panikov, N., Michaud, M., Gallini, C. A., Bohlooly, Y. M., et al. (2013). The microbial metabolites, short-chain fatty acids, regulate colonic Treg cell homeostasis. Science 341, 569-573. doi: 10.1126/science. 1241165

Spaiser, S. J., Culpepper, T., Nieves, C., Ukhanova, M., Mai, V., Percival, S. S., et al. (2015). Lactobacillus gasseri KS-13, Bifidobacterium bifidum G9-1, and Bifidobacterium longum MM-2 ingestion induces a less inflammatory cytokine profile and a potentially beneficial shift in gut microbiota in older adults: a randomized, double-blind, placebo-controlled, crossover study. J. Am. Coll. Nutr. 34, 459-469. doi: 10.1080/07315724.2014.983249

Srutkova, D., Schwarzer, M., Hudcovic, T., Zakostelska, Z., Drab, V., Spanova, A., et al. (2015). Bifidobacterium longum CCM 7952 promotes epithelial barrier function and prevents acute DSS-induced colitis in strictly strain-specific manner. PLOS ONE 10:e0134050. doi: 10.1371/journal.pone.0134050

Strisciuglio, C., Miele, E., Giugliano, F. P., Vitale, S., Andreozzi, M., Vitale, A., et al. (2015). Bifidobacteria enhance antigen sampling and processing by dendritic cells in pediatric inflammatory bowel disease. Inflamm. Bowel Dis. 21, 1491-1498. doi: 10.1097/MIB.0000000000000389

Sugahara, H., Yao, R., Odamaki, T., and Xiao, J. Z. (2017). Differences between live and heat-killed bifidobacteria in the regulation of immune function and the intestinal environment. Benef. Microbes 8, 463-472. doi: 10.3920/BM2016.0158

Sutterwala, F. S., and Flavell, R. A. (2009). NLRC4/IPAF: a CARD carrying member of the NLR family. Clin. Immunol. 130, 2-6. doi: 10.1016/j.clim.2008.08.011

Tailford, L. E., Crost, E. H., Kavanaugh, D., and Juge, N. (2015). Mucin glycan foraging in the human gut microbiome. Front. Genet. 6:81. doi: 10.3389/fgene. 2015.00081

Takahashi, N., Kitazawa, H., Iwabuchi, N., Xiao, J. Z., Miyaji, K., Iwatsuki, K., et al. (2006). Immunostimulatory oligodeoxynucleotide from Bifidobacterium longum suppresses Th2 immune responses in a murine model. Clin. Exp. Immunol. 145, 130-138. doi: 10.1111/j.1365-2249.2006.03111.x

Tan, T. G., Sefik, E., Geva-Zatorsky, N., Kua, L., Naskar, D., Teng, F., et al. (2016). Identifying species of symbiont bacteria from the human gut that, alone, can induce intestinal Th17 cells in mice. Proc. Natl. Acad. Sci. U.S.A. 113, E8141-E8150. doi: 10.1073/pnas.1617460113

Tanabe, S., Kinuta, Y., and Saito, Y. (2008). Bifidobacterium infantis suppresses proinflammatory interleukin-17 production in murine splenocytes and dextran sodium sulfate-induced intestinal inflammation. Int. J. Mol. Med. 22, 181-185. doi: 10.3892/ijmm_00000006

Turroni, F., Bottacini, F., Foroni, E., Mulder, I., Kim, J. H., Zomer, A., et al. (2010b). Genome analysis of Bifidobacterium bifidum PRL2010 reveals metabolic pathways for host-derived glycan foraging. Proc. Natl. Acad. Sci. U.S.A. 107, 19514-19519. doi: 10.1073/pnas.1011100107
Turroni, F., Foroni, E., O'Connell Motherway, M., Bottacini, F., Giubellini, V., Zomer, A., et al. (2010a). Characterization of the serpin-encoding gene of Bifidobacterium breve 210B. Appl. Environ. Microbiol. 76, 3206-3219. doi: 10.1128/AEM.02938-09

Turroni, F., Milani, C., Duranti, S., Mancabelli, L., Mangifesta, M., Viappiani, A., et al. (2016). Deciphering bifidobacterial-mediated metabolic interactions and their impact on gut microbiota by a multi-omics approach. ISME J. 10, 1656-1668. doi: 10.1038/ismej.2015.236

Turroni, F., Serafini, F., Foroni, E., Duranti, S., O'Connell Motherway, M., Taverniti, V., et al. (2013). Role of sortase-dependent pili of Bifidobacterium bifidum PRL2010 in modulating bacterium-host interactions. Proc. Natl. Acad. Sci. U.S.A. 110, 11151-11156. doi: 10.1073/pnas.1303897110

Turroni, F., Serafini, F., Mangifesta, M., Arioli, S., Mora, D., van Sinderen, D., et al. (2014). Expression of sortase-dependent pili of Bifidobacterium bifidum PRL2010 in response to environmental gut conditions. FEMS Microbiol. Lett. 357, 23-33. doi: 10.1111/1574-6968.12509

Van Kruiningen, H. J., West, A. B., Freda, B. J., and Holmes, K. A. (2002). Distribution of Peyer's patches in the distal ileum. Inflamm. Bowel Dis. 8, 180-185. doi: 10.1097/00054725-200205000-00004

Vieira, A. T., Galvão, I., Amaral, F. A., Teixeira, M. M., Nicoli, J. R., and Martins, F. S. (2015). Oral treatment with Bifidobacterium longum $51 \mathrm{~A}$ reduced inflammation in a murine experimental model of gout. Benef. Microbes 6, 799-806. doi: 10.3920/BM2015.0015

Vlasova, A. N., Chattha, K. S., Kandasamy, S., Liu, Z., Esseili, M., Shao, L., et al. (2013). Lactobacilli and bifidobacteria promote immune homeostasis by modulating innate immune responses to human rotavirus in neonatal gnotobiotic pigs. PLOS ONE 8:e76962. doi: 10.1371/journal.pone. 0076962

Wittmann, A., Autenrieth, I. B., and Frick, J.-S. (2013). Plasmacytoid dendritic cells are crucial in Bifidobacterium adolescentis-mediated inhibition of Yersinia enterocolitica infection. PLOS ONE 8:e71338. doi: 10.1371/journal.pone. 0071338

Wu, B.-B., Yang, Y., Xu, X., and Wang, W.-P. (2016). Effects of Bifidobacterium supplementation on intestinal microbiota composition and the immune response in healthy infants. World J. Pediatr. 12, 177-182. doi: 10.1007/s12519015-0025-3

Wu, M. H., Pan, T. M., Wu, Y. J., Chang, S. J., Chang, M. S., and Hu, C. Y. (2010). Exopolysaccharide activities from probiotic Bifidobacterium: immunomodulatory effects (on J774A.1 macrophages) and antimicrobial properties. Int. J. Food Microbiol. 144, 104-110. doi: 10.1016/j.ijfoodmicro.2010. 09.003

Yatsunenko, T., Rey, F. E., Manary, M. J., Trehan, I., Dominguez-Bello, M. G., Contreras, M., et al. (2012). Human gut microbiome viewed across age and geography. Nature 486, 222-227. doi: 10.1038/nature11053

Zelante, T., Fric, J., Wong, A. Y. W., and Ricciardi-Castagnoli, P. (2012). Interleukin-2 production by dendritic cells and its immunoregulatory functions. Front. Immunol. 3:161. doi: 10.3389/fimmu.2012. 00161

Zivkovic, A. M., German, J. B., Lebrilla, C. B., and Mills, D. A. (2011). Human milk glycobiome and its impact on the infant gastrointestinal microbiota. Proc. Natl. Acad. Sci. U.S.A. 108, 4653-4658. doi: 10.1073/pnas.1000083107

Conflict of Interest Statement: The authors declare that the research was conducted in the absence of any commercial or financial relationships that could be construed as a potential conflict of interest.

Copyright (C) 2017 Ruiz, Delgado, Ruas-Madiedo, Sánchez and Margolles. This is an open-access article distributed under the terms of the Creative Commons Attribution License (CC BY). The use, distribution or reproduction in other forums is permitted, provided the original author(s) or licensor are credited and that the original publication in this journal is cited, in accordance with accepted academic practice. No use, distribution or reproduction is permitted which does not comply with these terms. 